\title{
Un-hierarchical and hierarchical core-periphery relations: North Fennoscandian trade network from the Middle Ages to the post 16th century
}

\section{Introduction}

In this paper, we examine the un-hierarchical form of a core-periphery relationship as well as its working mechanisms and hypotheses on why in certain situations a core-periphery differentiation evolves into a core-periphery hierarchy. In particular, the paper draws inspiration from the medieval trade network of Fennoscandia by presenting two case studies involving archaeological and historical data from the pre-modern to historic times. We employ a macro-scale research strategy - the world-systems analysis - and, at the same time, highlight the manner in which local historical factors affect the working mechanisms of the system to a significant degree.

Theoretical discussion - world-system theory and its criticism

World-system theory introduced by Immanuel Wallerstein (see Wallerstein 2004; 2011) was - for a time - a popular theory for cultural changes and interactions in archaeology (for a recent review see Orser 2009). Principal to this theory is the idea of a division of labour within a bounded region and the exploitative relationship between the groups within that area.

The use of the theory in archaeology was subsequently criticised widely due to uncritical appliance of the model - or its derivatives - with the implicit assumption of a power asymmetry between what is deemed to be the core and what is deemed to be the periphery even though such assumptions may have had little basis in reality (e.g. Dietler 1995; McGuire 1996; Stein 1998). Criticism has also been directed at the world-system approach due to its preoccupation with the 
concept of "capitalism" in its traditional form, inevitably leading to a very narrow, Eurocentric, approach (McGuire 1996, 52; Denemark \& Gills 2012, 164-165, 169).

Equally disturbing for the critics has been the economic-deterministic approach of the theory and the following disregard of complexities of socio-political structures and their nuances, which may manifest for example as syncretism and creolisation (Webster 1997; 2005), bilateral borrowing and adaptation of cultural elements (Price 2002), selective adaptation, abandonment and re-adaptation of cultural elements (Webster 1999; Nurmi 2009; Kuusela et al. 2016) or simply as internal factors within a society that drive cultural change forward (Stein 1999; 2002). Put simply, the critics point out that the theory enforces a "one size fits all" -model on a sweeping manner ignoring local unique circumstances and resulting historical processes (McGuire 1996, 51; Galaty 2011, 4).

\section{Alternatives and amendments}

Colin Renfrew was among the early and arguably most famous critics of the use of the worldsystem theory in archaeological research, and he presented an alternative model, which he termed peer polity interaction (Renfrew 1986). Peer polity interaction, like world-system theory (from an archaeological perspective), tackles the problem of culture change and inter-regional interaction, and like world-system theory it, too, acknowledges that the latter is an integral part in these dynamics, and it shares with the world-system theory a systemic approach to the relations of human societies (McGuire 1996, 54). Where it significantly differs is that it does not acknowledge a power asymmetry or a dominative relationship between interacting parties but, like its name denotes, assumes such interactions take place between autonomous peers (Renfrew 1986, 1). 
Peer polity interaction has the advantage that it neither relies on nor presupposes a perceived asymmetry of power between participants in the interaction and is thus more amenable to the inclusion of local historical developments into the model than the criticised top-down deterministic view of world-system theory. Yet even the peer polity -model has been criticised for the same fault as the world-system theory - namely that it ultimately attempts to cover a wide range of societies and societal processes under a single totalizing model (McGuire 1996, 54-55, $60)$.

Attempts have been made to revise the world-system theory to respond to the criticism and to specifically allow it to be used in the analysis of prehistoric societies - something Wallerstein himself has been sceptical of (Wallerstein 1993). One view is the existence of several centres and peripheries in a complex network of interactions that do not form a single world-system as such, though they may very well be interconnected (e.g. Kohl 1989; Edens \& Kohl 1993, 31; Kristiansen \& Larsson 2005). Philip Kohl (1989) has also put forward the idea - using prehistoric West Asia as a case - that the difference between prehistorical cores and peripheries was far narrower than in modern times due to the technological difference between the two being small or non-existent. According to Kohl, this would have resulted in a far greater level of interdependence between the cores and the peripheries and accordingly also a far greater autonomy for the peripheries.

Denemark and Gills $(2012,169)$ in turn posit that the world-system theory is not "wrong" per se, rather than incomplete. They maintain that the mechanism as described by the theory is, by and large correct, but it transcends the timescale suggested by, for instance, Wallerstein himself. In other words, the mechanisms that make up the modern world-system were effectively in place long before the modern times and thus, in order to be a useful research framework, world-system theory must account for history - Denemark and Gills call this approach world-system history. 
The version of record of this manuscript has been published and is available in American Anthropologist 120 vol. 4, 765-780. doi: 10.1111/aman.13104

The inclusion of historical processes implicitly demands a more particularistic approach to each case. What this means concretely is, that the analysis needs to account for multiple trajectories of cultural change and thus, each case must be studied individually while maintaining a link to a larger framework to avoid being lost in extreme particularism (see Kardulias and Hall 2008, 573).

This more historical and particularistic approach has been endorsed by some archaeologists who have previously favoured the world-system theory - for instance Kristian Kristiansen and Thomas B. Larsson in their well-known 2005 book The Rise of Bronze Age Society put this in writing:

"Our ambition is to go beyond a macro-historical framework of the coreperiphery, world system theory by dissolving specific historical processes of interregional interaction into their various symbolic, economic and social components to trace their selective, local impact in the process." (Kristiansen and Larsson 2005: 5).

It should be emphasised, that even though Kristiansen's and Larsson's book revises especially Kristiansen's earlier views - which were heavily influenced by the world-system theory (e.g. Kristiansen 1987; 1998) - into a more moderate view relying more strongly on local analysis, the perspective of their book is still one of cores and peripheries.

In the end the key-issue in the criticism of world-system theory in archaeology comes down to its road-map view and the dominance of structure over agency, the dominance of a worldarching system over local historical and related social developments. The theory - if used as originally presented by Wallerstein - on the one hand assumes the existence of asymmetry between what is deemed to be the core and what is deemed to be the periphery, and on the other, at least 
implicitly, assumes this asymmetry is recognised by both parties - i.e. that the asymmetry and the existence of a dominative relationship are perceived to exist by the parties in question.

Though world-system approach may have been somewhat out of fashion among archaeologists recently - perhaps due to the popularity of post-modern research traditions favouring agency over structure and historical uniqueness over generalising approaches (Kardulias and Hall 2008, 572-573), it still has its proponents. For instance, Andre Gunder Frank maintained a view of a single world-system in existence since prehistory (Frank 1993; Frank and Thompson 2006), though his very extreme interpretations may be in the minority. Nick Kardulias together with Thomas Hall and Christopher Chase-Dunn in turn have kept a more moderate view and have written several papers in defence of the approach arguing, that while the critics of the worldsystems perspective have a point, a large part of their criticism is also misdirected. They point out, that the world-systems perspective has been amended and modified to address precisely the problem of its top-down deterministic view and that presently there is not one world-system theory, but rather a body of theories and methods of analysis - some competing - and the approach should nowadays be termed world systems-analysis (stress on the plural "systems") and not a world-system theory and that it should be understood as an approach - or a macro scale research strategy - and not a model to be applied mechanically (e.g. Kardulias and Hall 2008; Galaty 2011; Hall et al. 2011). Kardulias and others argue, that maintaining a generalised view in no way presupposes that the individual and local be ignored, and that to the contrary, both must be analysed together for the benefit of both (Kardulias and Hall 2008, 573; Hall et al. 2011, 240, 245). Also, it is apparent that in its more recent incarnations, the world-systems analysis no longer pre-assumes the existence of a hierarchy between the core and the periphery and the development of such is its own research question (Kardulias and Hall 2008, 576; Hall et al. 2011, 242). Nevertheless, 
Kardulias and Hall still maintain - though they admit exceptions to the rule - that in a coreperiphery -relationship, the former has the tendency to exploit the latter (Kardulias and Hall 2008, 576) implicitly still assuming an awareness of an asymmetric relationship between the two (but see Galaty 2011, 10-14).

Following Kardulias and others, we maintain that the generalising approach of worldsystems analysis is far from being outdated or useless while at the same time we most certainly acknowledge that the criticism over the last decades is well-placed. However, useful qualities should not be abandoned just because some parts of the theory are not useable. From our view, the useful part of the world-systems perspective is the view of human societies forming an interconnected network and the manner in which this network functions when all a priori presumptions regarding power relations are first abolished. Thus, we maintain that the idea of "cores" and "peripheries" as purely functional terms - i.e. in simplified form cores being the centre of manufactured items and peripheries the source of raw materials - is still valid as it is in many cases indisputable. However, no a priori assumptions regarding power asymmetry should be drawn from this fact alone, but this underlying difference between the core and the periphery should be acknowledged as the basis for an analysis as it will impact the premises based on which the social interaction network between societies within the region will be formed. Thus, using the terminology of Hall and others, we acknowledge - a priori - core-periphery differentiation, but not hierarchy (see Hall et al. 2011, 242-243).

Some might regard us as being world-systems analysts, but we must emphasise that we agree with McGuire when he criticises the world-systems perspective of assuming that the existence of a system presupposes that it is there to "do" something and that the core and the 
periphery are automatically polar opposites in their interactions within this system - the one exploitative the other exploited (McGuire 1996, 53).

In our view, a system is not necessarily built at all per se, it may come into existence organically due to human interaction, and agents - whose social structures and -realities cause the system to be - are not necessarily aware of it existing on a larger scale. Thus, for agents within the system, awareness of the system is not a social fact for the simple reason that the system does not enter within their perception. With such a statement we acknowledge both McGuire, who stresses the analytical importance of social relations over units such as cores and peripheries (McGuire 1996, 60), and scholars such as Hall, Chase-Dunn and Kardulias (Kardulias and Hall 2008; Hall et al. 2011; see also Galaty 2011) who maintain that the world-systems perspective is still not only useable, but very much a "work-in-progress".

\section{Northern Fennoscandia}

The region of study for this paper is the northern Fennoscandia where the view of a hierarchical core-periphery -relationship has, to this day, dominated the discussion to the point where northern communities have been assigned the role of passive recipients of culture emanating from the centres of the south since at least the Bronze Age (see e.g. Kristiansen 1987; Baudou 1988; see also Forsberg 2012 and Lavento 2012 for critical reviews). Ultimately the north has been regarded as a distant usufruct exploited by societies from these centres with the coastal lands finally being colonised by them (e.g. Vahtola 1980; 1998, 17-18; 2003, 46-48; Huurre 1983, 414-429; Wallerström 1997, 314; Enbuske 2008, 83; Haggrén 2015, 420-421; Hood 2015; for the coeval development in North Sea coast cf. Amundsen et al. 2003, 84-86; Hansen \& Olsen 2014, 141166). Roughly speaking, this view may be rooted in the belief of an ethnic division between the 
coastal- and inland peoples in the north during this time, with the coastal inhabitants being southern peasant immigrants and the inland inhabitants the ancestors of the present-day Sámi peoples (e.g. Vahtola 1980; Koivunen 1985, 73-74; Wallerström 1997, 305, 314-315; Hansen \& Olsen 2014 : 100-107, 152-155). Especially pertaining to the eastern part of the current case - i.e. the region that today lies within the borders of Finland - the conception of a core-directed exploitation and settlement during the Middle Ages has been voiced as recently as 2015 in a general review of the prehistory and Middle Ages of Finland (Haggrén 2015, 420-421; Halinen 2015, 424), though elsewhere in the book the active role of local societies during the time is acknowledged as well (Wessman \& Raninen 2015, 361-363; also Kuusela 2015; Hakamäki 2016; Kuusela et al. 2016). Thus, the view of the north as a distant periphery to be used and exploited by the cores at will is in no way regarded as an outdated perception today although a more nuanced view is starting to be endorsed.

Recent archaeological research has revealed that very little in the coastal archaeological evidence suggests that colonists would have formed a significant part of the coastal communities prior to the 16th century (for an in-depth analysis see Kuusela et al. 2016; see also Bergman and Ramqvist 2017). Neither the coastal- nor inland communities were agricultural societies during this time - this is reflected both in the site distribution patterns and artefactual evidence of which the former indicates a marine/riverine subsistence economy for the coastal-, and hunter/fisher economy for the inland communities (Kuusela 2013, 89-118) whereas the artefactual evidence in the north is devoid of agricultural implements which are prevalent in the south - among the assumed centres of the colonisation of the northern coastal zone (Kuusela 2015, 16-18; Kuusela et al. 2016, 181-183). This means that whereas ethnic diversity in the area was likely a fact (see Wallerström 1997), ethnic divergences between the different northern communities was likely not 
a significant factor in the functioning of the trading network - both inland and coastal communities

at the time were descended of local populations that had inhabited the region for millennia and had consequently also traded with each other for millennia (see Kuusela 2013; Kuusela et al. 2016; Bergman and Ramqvist 2017).

Thus, a closer examination of the northern trade network and its working mechanism is in order as an exploitative core-periphery view regarding the interaction of people in the north might not be accurate.

\section{Case studies}

It is our aim, by bringing the level of study to a local level, to acknowledge the larger context "world-systemic" view if so one wishes to call it - while at the same time taking into account the manner in which local, relatively particularistic, factors have a key role in shaping that very system.

We will do this by examining two cases - one a decidedly hierarchical core-periphery system and the other not so. Both examine the mechanics of northern Fennoscandian Lapp-trade. The first - a hierarchical core-periphery case - examines the mechanics of the post-16th century AD Lapp trade whereas the second examines the same from the pre-16th century, or medieval ${ }^{1}$, perspective. Our aim is to scrutiny the development process of the dynamics which eventually transform a non-hierarchical core-periphery system into a hierarchical one, while at the same time highlighting the observable differences between the two.

Post-16th century Lapp trade system, a hierarchical core-periphery relationship

During the 17th and 18th centuries, Sweden enforced strict trade policies in line with the period's mercantile ideology (Heckscher 1963, 112-115; Magnusson 2000, 40, 59-67; Schön \& Krantz 
2012, 541-543). In the Bothnian Bay, trade was channelled through towns of which none had rights to conduct foreign trade. Only the so-called stable towns, of which Stockholm as a capital of the Kingdom of Sweden - which at this time included the territory of what is today Finland was by far the most influential, could conduct foreign trade. Most of the Kingdom's towns were so-called inland towns ${ }^{2}$, which had rights to trade only with the inland peoples and stable towns (e.g. Heckscher 1963, 72-74, 110; Magnusson 2000, 66; Meinander 2011, 41; Figure 1).

The towns in the Bothnian Bay had only two stable towns - Stockholm and Turku (Figure 1) - to trade with and of these two Turku had a diminutive role (Ranta 1981, 66-68). Moreover, the inland towns were not allowed to trade with each other and all had dedicated rural trading areas - Lapps ${ }^{3}$ - whose people were their specific trading partners. Merchants were not allowed to trade with people from outside of their own trading area and the rural population was not allowed to trade with merchants from other than their own town and the commercial interaction between merchants and people from the Lapps had to occur at public market sites during dedicated fair periods (Virrankoski 1973, 372-377).

The dominance of a single centre monotonized the selection of available goods which is why the choice of imported commodities derived from the inventory of the Stockholm merchants and represented the foreign trade contacts of Stockholm in the European markets. This is mirrored in archaeological material - the find assemblages indicate a monotonous selection of commercial products from the Baltic trade routes (Elfwendahl 1999; Bergold et al. 2004; Rosén 2004; Nurmi 2011a; see also Majantie 2007 and authors within). Ceramics is mostly Dutch or German or of domestic Southern Scandinavian production, even British earthenware is mostly absent before the latter half of the 18th century, when the maritime trade was liberated. Same, very concentrated 
origin of goods is evident in other artefact groups such as glassware and clay pipes (Nurmi 2017; in press; for more see Nurmi 2011a, 74-94).

Similar phenomenon is observable throughout the Bothnian trade network up the furthermost hinterlands. The assemblages from the 17th and 18th century rural farms (e.g. Sundström 1995; Lindqvist and Granholm 2011; Nurmi 2011b), as well as rural market places in both coastal and inland regions (e.g. Cleve 1955; Wallerström 1995a; 1995b; Rydström 2006) all have revealed similar selection of commercial goods from the Bothnian trade network. The slight differences in the origin of the material between the different coastal towns and Lapps only highlight the influence of the personal contacts of the coastal town merchants. Since particularly by the latter half of the 17th century, trade in the coastal towns was concentrated in the hands of a few influential merchants holding key economic positions, the selection and origin of goods in the towns was based on the contact network of those Stockholm merchants who supplied them (Nurmi 2017, 116-117).

This post-16th century system is an example of how a hierarchical core-semi-peripheryperiphery mechanism works in the early modern Scandinavian context. In the North Baltic scale, the uncontested centre during this time was Stockholm, supported by the more diminutive Turku, to which and via which trade was channelled by the decrees and power of the administration of the Swedish Crown. The hold of the Crown over northern Fennoscandia was solid with trade being centred on the writ-founded towns in the coast. The inland was also under Swedish rule following the increasing measures the Crown - supported by the Lutheran Church - took from the early 17th century onwards in establishing an administrational order in the hinterlands (see e.g. Virrankoski 1985, 223-234; Onnela 1995, 150-169, 225-255; Pennanen 2000; Vahtola 2004, 158-159). The Bothnian coastal towns worked as semi-peripheries with the task of collecting raw-materials of the 
peripheral inland and rural regions (Lapps) with the town-based burghers acting as the middlemen and operators in this mechanism. These raw materials were then shipped towards Turku and/or Stockholm from where, in turn, refined goods such as glassware, ceramics, metal-ware and other finished goods flowed to the opposite direction. Goods imported from the centres towards the semi-peripheries and peripheries were strictly channelled through the designated centre of Stockholm, and thus their selection was limited to what Stockholm had to offer. The power asymmetry between the participants in this model is evident; the Swedish Crown dominated the system by setting the rules and its administration and legal decrees shaped the trade in the north.

This system, however, did not come into existence from nothing and whereas the post-16th century trade fits well with the idea of a hierarchical core-periphery relationship, its predecessor was something different albeit structurally similar.

The medieval Lapp trade system, a peer network

The Bothnian Bay region - the northernmost part of the Bothnian Gulf - was a crucial part of the northern trade network and specifically its major rivers and their estuaries were highly important as nodal points for traffic (Kuusela et al. 2016). These inlets acted as the interface between the sea and the inland where the goods transported through the network were collected to be shipped into the core areas of Fennoscandia and northern Europe. The region was also subject to the ice winter which set limits to overseas interaction as the sea was frozen nearly six months per year cutting off maritime access (Outhier 1744; Okkonen 2012). At the same time, travel into the inland was relatively easy across frozen waterways, swamps and lakes (Okkonen 2012, 169-170; Bergman et al. 2014). When the sea was open, the situation was reversed as movement into the inland was limited, due to the absence of a road network and the difficult terrain dominated by swamps and 
thick forests and was effectively possible mainly via major traversable waterways (Okkonen 2012: 169; Bergman et al. 2014).

The ice winter had a specific effect on interaction. If one wished to travel freely into the inland they had to be stationed in the coastal area after the ice had set in, while the sea voyage was possible only during the months the sea-route was open. This created a situation where the coastal communities effectively became gateway communities (e.g. Hirth 1978; see also Nicholas 2003) with whom one had to associate with when travelling inland (Okkonen 2012, 170). From this follows that the coastal communities, who were in the position to supervise trade and act as middlemen whom could not be ignored, could resist attempts of takeover or colonisation. This is shown by the fact that coastal archaeological sites maintained their distinctively local character well into the 15th century AD (for a thorough analysis on the subject see Kuusela et al. 2016). The coastal middlemen were therefore members of autonomous local communities who acted as an independent interface via which the medieval Baltic trade worked in the north. The way they conducted the inland-trade may be reconstructed by an analogy to the period depictions of the Swedish priest Olaus Magnus observed and written during the early 16th century.

In his book, Olaus Magnus makes several observations of northern inland trade. Firstly, he points out that during the winter people lived alongside rivers whereas during the summer they became scattered on a broader area and secondly, that the trade was a prevalent practise mostly conducted in specific locations - according to him, trade took place either on flat fields or on the ice of inland lakes (Olaus Magnus Gothus 2002, 84). This indicates that these activities were also conducted during the winter - a practise known to have persisted in the north until the 19th century (Nahkiaisoja 2003, 183; Symonds et al. 2015, 83-85). Considering the natural conditions of the northern inland, winter-trade was practical as the overland movement was relatively effortless 
when the land was frozen. The trade-prospects were also accelerated by wintering along the rivers and other waterways during the colder months because these frozen waterways were akin to "highways" facilitating a reasonably easy access to the inland regions from the coast. Olaus also mentions those with whom the inland people traded - Birkarls (Olaus Magnus Gothus 2002, 85). The Birkarls are known to have been the coast-based independent merchants who operated the northern trade during the late medieval period. These coastal traders are relatively welldocumented in the historical record although most of our knowledge about them stems from the 16th century when the organisation was already waning. At that time, the Birkarls were members of peasant families along the Bothnian Bay coast between Umeå and Tornio -regions (see Figure 1). They were particularly involved in the Lapland trade and held a high position among local societies - during the 16th century some of them even held local jurisdiction as county bailiffs (Steckzén 1964; Vahtola 1991; Wallerström 1995a, 239-242; Hansen \& Olsen 2014, 232-243; Hood 2015, 42; Miettinen 2016; Koskinen et al. 2016, 265-266). They also held an independent right to tax the inland populations (Hood 2015, 42-43), though this taxation was likely framed within a complex web of gifts and counter-gifts pertaining to, for example, marriages (see Bergman and Edlund 2016).

It is notable that the depiction of trade during this time is decidedly different from what it was post-16th century. Olaus Magnus describes how the inland people traded with and paid taxes to the Norwegians and Russians in addition to the Swedish king (Olaus Magnus Gothus 2002, 85) which is in contrast to post-16th century times when the trade was under strict Swedish control. These notions offer important details on the nature of the trade between the coastal and inland people and they gain more relevance when archaeological record is considered. 
The version of record of this manuscript has been published and is available in American Anthropologist 120 vol. 4, 765-780. doi: 10.1111/aman.13104

Following the analyses of the archaeologists Inga Serning (1960), Inger Zachrisson (1984), Matti Huurre (1983, 1986), Inga-Maria Mulk (1994; 1996), Helena Taskinen (1998), Eija Ojanlatva (2003), Julie Lund (2015) and Ville Hakamäki (Hakamäki 2016), Table 1 presents several archaeological assemblages (see Figure 2) depicting the typological provenance of the artefacts from medieval sites in the interior Fennoscandia. The artefacts from these sites rarely point towards one region, but instead assemblages tend to signify contacts towards east, west and south. Typologically, the assemblages are mirrored in those of the coast to a high degree (Kuusela et al. 2016, 187-192). Furthermore, the distribution of the North Finnish 9th and 14th century sites and medieval inland dwelling sites - often referred to as Sámi dwelling sites in literature documented in the northern reaches of Lapland (e.g. Hedman and Olsen 2009; Halinen 2016), show either a tendency to follow important historical routes (see Hakamäki and Kuusela 2013; Kuusela et al. 2016), many of which were travelled during the medieval period and later (see Nahkiaisoja 2003, 183-184; Tanska 2011, 26-27; Lilja 2013, 23), or to cluster around water bodies along these routes (Figure 3). Both factors are an indication of the considerable level of networking amongst the inland communities.

In the interior regions of northern Finland, the association with inland routes is perhaps best shown by the regions of Kainuu and Koillismaa (see Figures 1 and 3) - an area which brings together several important waterways reaching from southeast Finland, Russia, Bothnian Bay coast and Lapland. These routes have been travelled for millennia and their importance is also evident during the period concerned in the present paper, when, especially after the 9 th century, the amount of archaeological material increases dramatically (see Huurre 1986, 129-146; Taavitsainen 1990, 112-114; Kuusela 2014; Hakamäki 2015). The archaeological record of the area comprises of several cremation burials (e.g. Huurre 1986, 130-132), long-term dwelling/trading sites (Huurre 
1983, 403-407; Hakamäki 2016) and scores of stray finds, most of which are of foreign origin suggesting that the communities in the area frequently associated with traders. Also, the artefact assemblages from excavated sites tend to contain utilities and ornaments which have been imported from surrounding areas, and occasionally coins and other artefacts from the more faraway regions of Central Europe and the Middle-East. Corresponding evidence of long-distance contacts are also seen in several silver hoards, most of which have been found in the interior of northern Finland and seem to follow the old trading-routes (e.g. Björkman 1957; Sarvas 1986; Ojanlatva 2003; see also Hansen and Olsen 2004, 122-125; 2014, 76-79, 113-116).

Another inland focal point is located in Northern Ostrobothnia where several sites dating between the 9th and 14th centuries have been found in recent years. Based on archaeological evidence, the area has been strongly involved in trade. This is demonstrated by the excavated site of Viinivaaran itäpää (Figure 3) - located at the eastern end of a prominent ridge which can be used as a route to reach the Bothnian Bay coast as it connects to Kiiminkijoki River in the north and Oulujoki River in the south - where a cremation burial and several dwellings have been documented. Artefactual evidence points towards southwestern Finland and Russia but also includes objects linking the site towards west (Hakamäki 2016).

Two important observations rise from this analysis. Firstly, the corresponding nature of the coastal- and inland archaeological record supports the recently forwarded notion concerning the origin of the Birkarl -tradition as a local system instead of an imported one (Bergman \& Edlund 2016). Secondly, albeit the Birkarls were - especially during the latter years of the system's lifespan - closely associated with the Kingdom of Sweden, this was not the case previously as the coastal archaeological record up until at least the 15th century AD exhibits a regionally eclectic nature in the manner of the inland assemblages (Kuusela et al. 2016). This indicates that the coastal 
traders dealt with people from several different regions. Therefore, this system was a coreperiphery -system, but in a manner not unique to pre-modern systems it did not have one but several centres (Edens \& Kohl 1993, 31). It follows from this that the system was not built on the dominance of the core(s) over the peripheries but worked in a different manner.

Traders from the south traded refined goods in exchange for furs, skins, fish and other northern goods, but the operative social structures were not based on domination. Unlike in the post-16th century system, the power asymmetry between the parties was not pronounced during medieval times although, at first sight it would seem that this unbalance is evident. By the 14th century, the Kingdom of Sweden was well-established, and no matching geo-political entity existed in the Bothnian Bay region. Yet Sweden had surprisingly little control over what it politically considered to be its northern domains. These areas were not conquered nor where they colonised during this time (Kuusela et al. 2016) and yet the network remained functional. The reason for the inability of the Swedish Crown to seize the network is crystallised in the problems related with control. Conquering the land and its people was simply not enough as it was information that mattered the most. Returning to the depictions of Olaus Magnus, he states how the inland people living in the vast wilderness of the north could not even be found unless they wanted to be found (Olaus Magnus Gothus 2002, 82). This meant that the knowledge of when and where they would be, as well as trusted contacts within their communities, were essential for anyone who wished to trade with them. This effectively made simple land-grab a futile effort from the perspective of taking control of the trade. Even if the Crown had conquered the northern coasts, they would not have gained the required inland contacts and thus such a display of force would have been counter-productive. Furthermore, a conquered land would have required resources to keep it pacified - resources the kings of Sweden would not have had access to for some time to 
come, as the power of the king was still very much curtailed before the 16th century (Heckscher 1963, 61-78; Andersson 1970, 120-141; Sawyer and Sawyer 1993, 58; Kent 2008, 16-70; cf. also Hallenberg et al. 2008).

Based on the above, a hierarchical core-periphery system was out of the question, and the relationship between the core and the periphery was based on the interaction of peers - thus trade occurred more or less based on the principles of peer polity interaction as defined by Renfrew (see also Stein 1998). Though a power asymmetry is perhaps evident, when observed top-down, this asymmetry could not be brought to bear on the relationship itself, thus negating it.

\section{From a non-hierarchical to a hierarchical core-periphery -relationship}

After the 16th century, something happened to the medieval peer network which effectively transposed it into a hierarchical core-periphery relationship. To understand this change, we must briefly review the historical development of the Swedish state during the 16th century.

Before the 16th century the state of Sweden was still internally quite incoherent. The Kingdom had grown from allied Iron Age and medieval counties and king-/chiefdoms and involved thus a number of power elements with their own interests. Gustav Vasa was elected the King of Sweden in 1523 and he began the reformation that led to the birth of the Swedish state proper. His and his succerssors' efforts were centred on economic reforms that were designed to support the individual power of the king and included the creation of an administrative organisation of bailiffs directly responsible to the king as well as a meticulous inventory of all the assets available for taxation (Hallenberg et al. 2008, 251-252; Hallenberg 2012, 563). Later, in the latter phase of the 16th century, this process was halted due to costly wars and the Swedish state was in no condition to exert strong central control over its domains (Hallenberg et al. 2008, 254; 
Miettinen 2016, 234-235). Thus, the sphere of economy and power was tightly intertwined throughout the 16th century within the Kingdom of Sweden.

The above falls woefully short in describing the very complex process of Swedish state formation, but the space constraints of an article do not allow for a lengthy study of the subject here. Suffice to say, that when changes began in the north during the 16th century, they fell in line with a general pattern of strengthening state control and the culling of privileges across the Kingdom of Sweden as well as the mistreatments and violence that followed (see Koskinen et al. 2016; Holm 2016). With the increasing state control, the state's administrative ability increased as well (see Retsö 2009; Hallenberg 2012), and this enabled the crown to change its relationship with the north.

Prior to the 16th century, the Swedish Crown supported and strengthened the privileges of Birkarls in Lapland by repeatedly issuing ratifications (cf. Wallerström 1995a, 239-242), but during the 16th century the Crown's attitude changed (Steckzén 1964, 323; Hallenberg et al. 2008, 251; Miettinen 2016, 234). As King Vasa aimed to strengthen and standardize the Crown taxation throughout the kingdom, the Birkarl rights were discontinued in 1553 (Vahtola 1991, 218; Hood 2015, 42). This resulted in Birkarls losing their independent right to tax the inland peoples but allowing them to continue the profitable Lapland trade itself. However, from the 1570s onwards the Crown wanted to abolish the Birkarl trade altogether, and to find a merchant-based system centred on towns and market areas (Ranta 1981, 53; Vahtola, 1991, 221; Miettinen 2016, 234236). This struggle finally ended in the Birkarls' defeat when the town of Tornio was established in the estuary of Tornionjoki River in 1621- the last stronghold of Birkarl traders in the north (cf. e.g. Mäntylä 1971, 7-24; Nurmi 2011a, 19-21; Miettinen 2016, 236). 
When the Crown abolished the Birkarls' taxing rights it continued to rely on the system itself in taxing its Lapland territories. The Crown promoted members of the influential Birkarl families into county bailiffs and appointed them to oversee and execute Crown taxation (e.g. Miettinen 2016, 234). The Crown had little choice. Only the Birkarls had the necessary intangible resources - information and personal contacts - to facilitate both trade and taxation in the inland, and thus the Crown had to rely on them (see Luukko 1954, 527-528; Olofsson 1962; Steckzén 1964, 258-324; Mäntylä 1971; Lundholm 1991; Vahtola 1991, 221). However, the new settings put the Birkarls into a double-role position, as while representing the Crown's interests, they continued maintaining their old personal economic and social interests (Hood 2015, 42). Thus when the Crown issued the Birkarls the right to act as county bailiffs, it disrupted the power balance in the old peer network and began to cause friction and conflicts between the Birkarls and the inland communities, erupting into an expanding number of legal complaints against them (Luukko 1954, 538-542; Steckzén 1964, 340-346; Hood, 2015, 43; Miettinen 2016, 244).

The 16th century records involving the complaints over the actions of the Birkarl bailiffs draws a different image of the relations between the two parties in comparison to the earlier historical documents and, for example, the period narratives of Olaus Magnus. Recently, the Swedish scholars Ingela Bergman and Lars-Erik Edlund (2016) have convincingly emphasized that originally the Birkarls were more a part of the inland- than coastal communities and their position was based on mutual trust and co-operation. However, by first abolishing the independent taxing rights and then setting Birkarls as crown bailiffs to oversee state taxing, the Crown interfered with this cohesion. Such externally operated rearrangement ultimately accelerated the downfall of the Birkarl system. 
The use of Birkarls as crown bailiffs was efficient and logical because of their indispensable knowledge of local natural and social conditions (Hood 2015, 42; cf. also Luukko 1954, 523-575). The new power-asymmetry proved advantageous for the Crown as by the end of the 16th century the northern coastal region was socially ripe to accept the Swedish urban system and one by one the old Birkarl trade usufructs were merged into the Swedish trade network by founding new towns (e.g. Mäntylä 1971, 13-16; Miettinen 2016, 236) and eventually by creating a rigid trade hierarchy involving stable- and inland towns (Ranta 1981, 66).

\section{Conclusions}

The north was economically important for several of the medieval powers operating in the Baltic sphere - the Kingdom of Sweden, Hanseatic League and the Republic of Novgorod. Yet before the 16th century, none of these managed to enforce a dominative relationship over the north. The reason for this was that the northern coastal merchants controlled a key-resource that could not be simply taken away - information. Thus, forcing a dominative relationship over the periphery in the north would have been counter-productive and detrimental to the economic goals of the relationship. Also, despite the key role of coastal communities in the network, they in turn were unable to dominate the inland communities they were trading with as their relationship was based on mutual trust and co-operation and relied on the inland people meeting the coastal traders at set times in set places. The inland communities, who conducted the acquisition of resources and materials for trade, could also choose their trading partners and they could also have had trade connections to several directions in the northern trade network.

A system of core-periphery relationship was in existence prior to the 16th century, but the social dynamics within it were significantly different than in a hierarchical core-periphery system. 
This un-hierarchical system was organically created by the societies themselves and was based on a perceived peer-interaction as per the idea of peer polity interaction. In this network, everyone perceived themselves as being the centre of the network and acted per their own interests with whom they perceived to be their peers. They were likely aware of the network only to a limited degree - possibly only extending to their immediate contacts.

The organic nature of such systems has been brought in to discussion by implication before. Charles Orser $(2009,254,256)$ summed up in his review that: "Modernisation theorists tend to believe that all peoples, regardless of their customs, belief systems or locations in the world, can start the road to modernity given the proper conditions." This apparently refers to the organic nature of world-systems, albeit holding on to the concept of the influence of superiority. Reno (1996) has pointed out that social relations may be a more fruitful line of inquiry than a dogmatic adherence to world-systems theory, echoing the words of McGuire $(1996,60)$ who points out that interest should be directed towards social relations instead of generalising units. In other words, non-hierarchical and hierarchical core-periphery systems are comparable only from the functional point of view, which indicates that the network-system in it, is virtually always the same but the directive powers differ. Thus, the framework is the organic part of the system. In a hierarchical core-periphery system the definitive power asymmetry is a prerequisite, but like many critics of the world-systems approach have pointed out, archaeological research cannot presume a power asymmetry in the network.

Archaeologically hierarchical and non-hierarchical systems manifest differently in the periphery. In a non-hierarchical system, based on what effectively is peer-networking, the imports in the archaeological assemblage of the periphery exhibit a regionally eclectic character especially in the case when the periphery has contacts towards several cores. If one core takes control and 
transforms the relationship into a hierarchical core-periphery -relationship, it appears to have the tendency of making the imports in the periphery more uniform and monotonous than previously. This is also apparent in northern Fennoscandia where the archaeological assemblages are eclectic prior to the 16th century but become increasingly uniform when the hold of the Swedish Crown solidifies.

Socially, the distinction between a hierarchical and a non-hierarchical system is a profound one. A non-hierarchical network does not - indeed cannot - operate based on dominance and exploitation and therefore the very premise for the interaction is completely different from what it would implicitly be if the analysis would assume the existence of a hierarchical relationship.

\section{Notes}

Acknowledgements

We gratefully acknowledge the anonymous reviewers for their helpful comments and the time and effort they put on reviewing the manuscript. Any mistakes are naturally the responsibility of the authors.

\section{Endnotes}

1. The Scandinavian medieval period comprises the time from the decline of the Vikings and the rise and spread of Catholic Church through the northern Europe to the coronation of Gustav Vasa, i.e. from 1000-1300 AD to 1520s AD (e.g. Sawyer and Sawyer 1993, ix-xvi; Helle 2003). The actual conception of the beginning of the medieval period varies between the Nordic countries. Southern Scandinavia entered the Middle Ages by the 11th century AD, but in the north, and in the most part of Finland particularly, the Middle Ages are considered to begin by the late 13th- 
The version of record of this manuscript has been published and is available in American Anthropologist 120 vol. 4, 765-780. doi: 10.1111/aman.13104

early 14th centuries $\mathrm{AD}$, when the first evidence of the presence of ecclesiastic organizations appear (Lavery 2006, 25-28). In this paper we follow the latter designation of the Middle Ages as it best suits the study region.

2. This is the terminologically correct term for a town without trading rights, it has no bearing on whether the town was situated inland or not (Meinander 2011, 41).

3. This is again the terminologically correct term for these trading areas. Not to be confused with the groups of inland people referred to as "Lapps" (see e.g. Träsk 1928; Enbuske 2008, 87-90, $125-130)$.

\section{References}

Amundsen, Colin, Henriksen Jørn, Myrvoll, Elin, Olsen, Bjørnar and Urbanczyk, Przemyslaw. 2003. "Crossing borders: Multi-room houses and inter-ethnic contacts in Europe's extreme north." Fennoscandia Archaeologica 20: 79-100.

Andersson, Ingvar. 1970. A History of Sweden. Stockholm: Natur och Kultur.

Bergman, Ingela, and Edlund, Lars-Erik. 2016. "Birkarlar and Sámi - inter-cultural contacts beyond state control: reconsidering the standing of external tradesmen (birkarlar) in medieval Sámi societies." Acta Borealia 33(1): 52-80. doi: 10.1080/08003831.2016.1154676

Bergman, Ingela and Ramqvist, Per H. 2017. "Farmer-fishermen: interior lake fishing and intercultural and intra-cultural relations among coastal and interior Sámi communities in northern Sweden AD 1200-1600.” Acta Borealia 34(2): 134-158. doi: 10.1080/08003831.2017.1390662 
Bergman, Ingela, Zackrisson, Olle and Östlund, Lars. 2014. “Travelling in boreal forests: routes of communication in pre-industrial northern Sweden." Fennoscandia Archaeologica 31: 45-60.

Bergold, Helmut, Bäck, Mathias, Johansson, Mikael, Menander, Hanna, Niukkanen, Marianna, Tulkki, Carita, and Wallebom, Ulrika. 2004. "Handled with care - on the typology and symbolism of redware pottery." Muinaistutkija 2004(2): 2-25.

Björkman, Tuomas. 1957. “Kuusamon Lämsän hopea-aarre.” Suomen museo 64: 17-34.

Cleve, Nils. 1955. “Kemin Haminasaaren markkinapaikka.” Jatuli 5: 3-17.

Denemark, Robert A., Gills, Barry K. 2012. "World-system history. Challenging Eurocentric knowledge.” In Routledge Handbook of World-Systems Analysis, edited by Christopher K. ChaseDunn and Salvatore J. Babones, 117-122. London, New York: Routledge.

Dietler, Michael. 1995. "The cup of Gyptis: rethinking the colonial encounter in early-Iron-Age Western Europe and the relevance of world-systems models." European Journal of Archaeology 3(2): 89-111. doi: 10.1179/096576695800703720

Edens, Christopher M., and Kohl, Philip. 1993. "Trade and world systems in Early Bronze Age western Asia." In Trade and Exchange in Prehistoric Europe, edited by C. Scarre and F. Healy, 17-34. Oxford: Oxbow Books. 
Elfwendahl, Magnus. 1999. Från skärva til kärl: Ett bidrag till vardagslivet i Uppsala. Lund: Almqvist \& Wiksell International.

Enbuske, Matti. 2008. Vanhan Lapin valtamailla: asutus ja maankäyttö historiallisen Kemin Lapin ja Enontekiön alueella 1500-luvulta 1900-luvun alkuun. Helsinki: Suomalaisen Kirjallisuuden Seura.

Forsberg, Lars. 2012. "Asymmetric twins? Some reflections on coastal and inland societies in the Bothnian area during the Epineolithic and Early Metal Age." In Local Societies in Bronze Age Northern Europe, edited by N. Anfinset and M. Wrigglesworth, 31-55. Sheffield: Equinox.

Frank, Andre G. 1993. "Bronze Age world system cycles”. Current Anthropology 34: 383-429.

Frank, Andre G. and Thompson, William R. 2006. "Early Iron Age economic expansion and contraction revisited." In Globalization and Global History, edited by B.K. Gills and W.R. Thompson, 139-162. London and New York: Routledge.

Galaty, Michael L. 2011. "World-systems analysis and anthropology: a new détente?” Reviews in Anthropology 40: 3-26. doi: 10.1080/00938157.2011.547752 
The version of record of this manuscript has been published and is available in American Anthropologist 120 vol. 4, 765-780. doi: 10.1111/aman.13104

Hakamäki, Ville. 2015. "Artefacts, communication and the social change in the northern Finland interior ca. 800-1300 AD.” In Transcultural Encounters, edited by K. Alenius and V.-P. Lehtola, 111-130. Rovaniemi: Pohjois-Suomen historiallinen yhdistys.

Hakamäki, Ville. 2016. "Late Iron Age transculturalism in the northern "periphery": understanding the long-term prehistoric occupational area of Viinivaara E, Finland.” Acta Borealia 33(1): 30-51. doi: $10.1080 / 08003831.2016 .1154674$

Hakamäki, Ville and Kuusela, Jari-Matti. 2013. "Examining the topography and social context of metal age artefact finds in northern Finland." Fennoscandia Archaeologica 30: 95-106.

Hedman, Sven-Donald, and Olsen, Bjørnar. 2009. "Transition and order: a study of Sámi rectangular hearths in Pasvic, arctic Norway." Fennoscandia Archaeologica 26: 3-22.

Haggrén, Georg. 2015. “Asuinpaikat ja asumukset.” In Muinaisuutemme jäljet. Suomen esi- ja varhaishistoria kivikaudelta keskiajalle, edited by G. Haggrén, P. Halinen, M. Lavento, S. Raninen \& A. Wessman, 420-423, 425-471. Gaudeamus: Helsinki.

Halinen, Petri. 2015. "Saamelaiset rautakaudella ja keskiajalla." In Muinaisuutemme jäljet. Suomen esi- ja varhaishistoria kivikaudelta keskiajalle, edited by G. Haggrén, P. Halinen, M. Lavento, S. Raninen \& A. Wessman, 424-425. Helsinki: Gaudeamus. 
The version of record of this manuscript has been published and is available in American Anthropologist 120 vol. 4, 765-780. doi: 10.1111/aman.13104

Halinen, Petri. 2016. "The inland Sámi societies of northern Fennoscandia during the Late Iron Age and early medieval period: an archaeological approach." In New Sites, New Methods. Proceedings of the Finnish-Russian Archaeological Symposium, edited by: P. Uino and K. Nordqvist, 160-174. Helsinki: Suomen arkeologinen seura.

Hall, Thomas D., Kardulias, Nick and Chase-Dunn, Cristopher. 2011. "World-systems analysis and archaeology: continuing the dialogue.” Journal of Archaeological Research 19(3): 233-279. doi: 10.1007/10814-010-9047-5

Hallenberg, Mats. 2012. "For the wealth of the realm. The transformation of the public sphere in Swedish politics, c. 1434-1650." Scandinavian Journal of History 37(5): 557-577. doi: $10.1080 / 03468755.2012 .716638$

Hallenberg, Mats, Holm, Johan and Johansson, Dan. 2008. "Organisation, legitimation, participation. State formation as a dynamic process - the Swedish example, c. 1523-1680." Scandinavian Journal of History 33(3): 247-268. doi: 10.1080/03468750802150242

Hansen, Lars Ivar and Olsen Bjørnar. 2004. Samenes historie fram til 1750. Oslo: Cappelen Akademisk Forlag.

Hansen, Lars Ivar and Olsen Bjørnar. 2014. Hunters in transition: an outline of early Sámi history. Leiden: Brill. 
The version of record of this manuscript has been published and is available in American Anthropologist 120 vol. 4, 765-780. doi: 10.1111/aman.13104

Heckscher, Eli F. 1963. An Economic History of Sweden. Cambridge: Harvard University Press.

Helle, Knut. 2003. “Introduction.” In The Cambridge History of Scandinavia Vol. 1., edited by K. Helle, 1-12. Cambridge: Cambridge University Press.

Hirth, Kenneth G. 1978. "Interregional trade and the formation of prehistoric gateway communities." American Antiquity 43(1): 35-45.

Holm, Johan. 2016. ”The lost political uprisings." In Aggressive and Violent Peasant Elites in the Nordic Countries, C. 1500-1700, edited by U. Koskinen, 171-188. Cham: Springer International Publishing

Hood, Bryan C. 2015. "Framing Sámi entanglement in early modern colonial processes: ethnohistorical and archaeological perspectives from interior north Norway." Arctic Anthropology 52(2): 37-56. doi: 10.3368/aa.52.2.37

Huurre, Matti. 1983. Pohjois-Pohjanmaan ja Lapin historia I: Pohjois-Pohjanmaan ja Lapin esihistoria. Kuusamo: Pohjois-Pohjanmaan maakuntaliiton ja Lapin maakuntaliiton yhteinen historiatoimikunta.

Huurre, Matti. 1986. "Esihistoria." In Kainuun historia I, edited by M. Huurre and J. Keränen, 5200. Kajaani: Kainuun maakuntaliitto. 
The version of record of this manuscript has been published and is available in American Anthropologist 120 vol. 4, 765-780. doi: 10.1111/aman.13104

Kardulias, Nick and Hall, Thomas D. 2008. "Archaeology and world-systems analysis". World Archaeology 40(4): 572-583. doi: 10.1080/00438240802453252

Kent, Neil. 2008. A Concise History of Sweden. Cambridge: Cambridge University Press.

Kohl, Philip. 1989. "The use and abuse of world-systems theory: the case of the "pristine" West Asian State.” In Archaeological Thought in America, edited by C.C. Lamberg-Karlovsky, 241267. Cambridge: Cambridge University Press.

Koskinen, Ulla, Dørum, Knut, Hallenberg, Mats, Holm, Johan, Katajala, Kimmo, Miettinen, Tiina and Rian Øystein. 2016. "Conclusion: resisting, cooperating, and fighting." In Aggressive and Violent Peasant Elites in the Nordic Countries, C. 1500-1700, edited by U. Koskinen, 261-299. Cham: Springer International Publishing

Kristiansen, Kristian. 1987. "Centre and periphery in Bronze Age Scandinavia." In Centre and Periphery in the Ancient World, edited by M. Rowlands, M. Larsen and K. Kristiansen, 75-85. Cambridge: Cambridge University Press.

Kristiansen, Kristian. 1998. Europe Before History. Cambridge: Cambridge University Press.

Kristiansen, Kristian, and Larsson, Thomas B. 2005. The Rise of Bronze Age Society. Travels, Transmissions and Transformations. Cambridge: Cambridge University Press. 
The version of record of this manuscript has been published and is available in American Anthropologist 120 vol. 4, 765-780. doi: 10.1111/aman.13104

Kuusela, Jari-Matti. 2013. Political Economy of Bronze- and Iron Age Societies in the Eastern Coast of the Bothnian Bay ca. 1500 BC-AD 1300. PhD diss. Oulu: University of Oulu.

Kuusela, Jari-Matti. 2014. "From coast to inland. Activity zones in North Finland during the Iron Age.” In Fibula, Fabula, Fact. The Viking Age in Finland, edited by J.s Ahola, Frog and C. Tolley, 219-241. Helsinki: Finnish Literature Society.

Kuusela, Jari-Matti. 2015. “Iin Illinsaaren Suutarinniemen myöhäisrautakautinen kalmisto ja sen konteksti." Faravid 40: 5-30.

Kuusela, Jari-Matti, Nurmi Risto and Hakamäki, Ville. 2016. "Co-existence and colonisation: reassessing the settlement history of the pre-Christian Bothnian Bay coast." Norwegian Archaeological Review 49(2): 177-203. doi: 10.1080/00293652.2016.1260048

Lavento, Mika. 2012. "Local centres in the periphery: the Late Neolithic, Bronze Age and Early Metal Age in Finland." In Local Societies in Bronze Age Northern Europe, edited by N. Anfinset and M. Wrigglesworth, 148-168. Sheffield: Equinox.

Lavery, Jason. 2006. The History of Finland. Westport: Greenwood Press.

Lilja, Erkki. 2013. Jäämerenkäytävä. Pohjois-Suomen rata- ja tiehankkeiden historiaa. Kerava: Hipputeos Oy. 
The version of record of this manuscript has been published and is available in American Anthropologist 120 vol. 4, 765-780. doi: 10.1111/aman.13104

Lindqvist, Anna-Karin, and Granholm, Nina. 2011. Särskild arkeologisk utredning. Etapp 2 inför alternative sträckning av E4, sk Inre alternativet, Umeå kommun, Västerbottens län. Excavation report, Umeå: Västerbottens Museum/Uppdragsverksamheten.

Lund, Julie. 2015. "Living places or animated objects? Sámi sacrificial places with metal objects and their South Scandinavian parallels." Acta Borealia 32(1): 20-39. doi: $10.1080 / 08003831.2015 .1029846$

Magnusson, Lars. 2000. An Economic History of Sweden. London and New York: Routledge.

Majantie, Kirsi, ed. 2007. Pots and princes: Ceramic vessels and stove tiles from 1400-1700. Turku: Aboa Vetus \& Ars Nova/SKAS.

McGuire, Randall H. 1996. "The limits of world-systems theory for the study of prehistory" In Pre-Columbian World Systems, edited by P.N. Peregrine and G.M. Feinman, 51-64. Madison Wisconsin: Prehistory Press.

Meinander, Henrik. 2011. A History of Finland. London: Hurst \& Company.

Miettinen, Tiina. 2016. "The Fordell family: a struggle for trade after three generations in power". In Aggressive and Violent Peasant Elites in the Nordic Countries, C. 1500-1700, edited by U. Koskinen, 229-260. Cham: Springer International Publishing 
The version of record of this manuscript has been published and is available in American Anthropologist 120 vol. 4, 765-780. doi: 10.1111/aman.13104

Mulk, Inga-Maria. 1994. Sirkas: ett samiskt sångstsamhälle i förändring Kr.f.-1600 e.Kr. Umeå: Umeå University.

Mulk, Inga-Maria. 1996. "The Role of the Sámi in fur trading in the Late Iron Age and Nordic medieval period in the light of Sámi sacrificial sites in Lapland, northern Sweden.” Acta Borealia 13(1): 47-80. doi: 10.1080/08003839608580447

Nahkiaisoja, Tarja. 2003. Uudisasuttajien aika (1750-1860). In Inari - Aanaar. Inarin historia jääkaudesta nykypäivään, edited by V.-P. Lehtola, 164-215. Inari: Inarin kunta.

Nicholas, David. 2003. Urban Europe, 1100-1700. Basingstoke: Palgrave Macmillan.

Nurmi,Risto. 2009. "The others among us? Saami artefacts in a 17th century urban context in the town of Tornio, northern Finland." In Máttut - Máddagat: The Roots of Saami Ethnicities, Societies and Spaces/Places, edited by T. Äikäs, 68-87. Oulu: University of Oulu.

Nurmi, Risto. 2011a. Development of the urban mind - an object biographical approach. The case study of the town of Tornio, northern Finland. PhD diss., Oulu: University of Oulu.

Nurmi, Risto. 2011b. "Paluu Pohjois-Suomen Historiallisen ajan maaseutuarkeologiseen aineistoon - Rovaniemen Ylikylä puuttuvien pottien tapaus.” In Harmaata näkyvissä - Kirsti Paavolan juhlakirja, edited by J. Ikäheimo, R. Nurmi and R. Satokangas, 209-220. Oulu: University of Oulu. 
Nurmi, Risto. 2017. "Kuinka talonpojista tuli porvareita - arkeologinen näkökulma torniolaisten kaupunkilaistumiseen 1600-luvulta 1800-luvulle.” Tornionlaakson Vuosikirja 2015-2017: 106147.

Nurmi, Risto. in press. "The first century of the town of Tornio - urbanization in the northern edge of Europe." In The Oxford Handbook of Historical Archaeology, edited by J. Symonds and V.-P. Herva. Oxford: Oxford University Press.

Ojanlatva, Eija. 2003. "A late Iron Age silver deposit found at Nanguniemi, Inari, Finland." Fennoscandia Archaeologica 20: 115-119.

Olaus Magnus Gothus. 2002. Olaus Magnus. Suomalaiset Pohjoisten kansojen historiassa. Edited and translated by K. Linnilä. Jyväskylä: Gummerus Kirjapaino Oy. First published 1555.

Onnela, Samuli. 1995. "Sodankylä, Sompio ja Kemikylä osana Kemin Lappia vuoteen 1747.” In Suur-Sodankylän historia 1, edited by A. Kehusmaa and S. Onnela, 81-261. Jyväskylä: Gummerus Kirjapaino Oy.

Okkonen, Jari. 2012. "Ympäristötekijät ja yhteisöjen vuorovaikutus Itämeren piirissä keskineoliittisella kaudella." In Itämeren itälaidalla III. Vallankäyttö Suomen ja Baltian historiassa. On the Eastern Edge of the Baltic Sea. Exercise of Power in the History of Finland 
The version of record of this manuscript has been published and is available in American Anthropologist 120 vol. 4, 765-780. doi: 10.1111/aman.13104

and the Baltic, edited by K. Alenius, 157-171. Rovaniemi: Pohjois-Suomen historiallinen yhdistys.

Outhier, Réginald. 1744. Journal d'un Voyage au Nord en 1736 \& 1737. Paris: chez Piget.

Orser, Charles E. 2009. "World-systems theory, networks and modern world archaeology." In International Handbook of Historical Archaeology, edited by T. Majewski and D. Gaimster, 253268. New York: Springer.

Pennanen, Jukka. 2000. ”Luonnonuskonnosta kristinuskoon. Uskonnollisten maailmankuvien kohtaaminen.” In Siiddastallan. Siidoista kyliin, edited by J. Pennanen and K. Näkkäläjärvi, 218220. Oulu: Pohjoinen.

Price, Neil S. 2002. The Viking Way. Religion and War in the Late Iron Age Scandinavia. Uppsala: Uppsala University.

Ranta, Raimo. 1981. "Suurvalta-ajan kaupunkilaitos." In Suomen kaupunkilaitoksen historia 1, Keskiajalta 1870-luvulle, edited by P. Tommila, 51-134. Helsinki: Suomen kaupunkiliitto.

Renfrew, Colin. 1986. "Introduction: peer polity interaction and socio-political change." In Peer Polity Interaction and Socio-Political Change, edited by C. Renfrew and J.F. Cherry, 1-18. Cambridge: Cambridge University Press. 
The version of record of this manuscript has been published and is available in American Anthropologist 120 vol. 4, 765-780. doi: 10.1111/aman.13104

Reno, R. L. 1996. Fuel for the frontier: Industrial archaeology of charcoal production in the Eureka mining district, Nevada, 1869-1891. PhD Thesis, University of Nevada: USA.

Retsö, Dag. 2009. Länsförvaltningen i Sverige 1434-1520. Stockholm: University of Stockholm.

Rydström, Gunhild. 2006. Det äldsta Lycksele - Öhn. Lycksele: Skogsmuseet.

Sarvas, Pekka. 1986. "Raha-aarteita Kuusamosta.” In Kuusamon historia 4, edited by A. Sarvas, 226-266. Kuusamo: Koillissanomat Oy.

Sawyer, Birgit, and Sawyer, Peter. 1993. Medieval Scandinavia. From Conversion to Reformation circa 800-1500. Minneapolis: University of Minneapolis Press.

Schön, Lennart and Krantz, Olle 2012. "The Swedish economy in the early modern period: constructing historical national accounts." European Review of Economic History 16: 529-549. doi: 10.1093/ereh/hes015

Serning, Inga. 1960. Övre Norrlands järnålder. Umeå: Umeå Research Library.

Steckzén, Birger. 1964. Birkarlar och lappar, En studie i birkarleväsendets, lappbefolkningens och skinnhandels historia. Stockholm: Almqvist \& Wiksell. 
The version of record of this manuscript has been published and is available in American Anthropologist 120 vol. 4, 765-780. doi: 10.1111/aman.13104

Stein, Gil J. 1998. "World system theory and alternative modes of interaction in the archaeology of culture contact." In Studies in Culture Contact: Interaction, Culture Change, and Archaeology, edited by James G. Cusick, 220-254. Carbondale: Southern Illinois University Press.

Stein, Gil J. 1999. "Rethinking world-systems: power, distance, and diasporas in the dynamics of interregional interaction." In World-Systems Theory in Practice. Leadership, Production, and Exchange, edited by P. Nick Kardulias, 153-177. Lanham, Boulder, New York, Oxford: Rowman \& Littlefield Publishers Inc.

Stein, Gil J. 2002. "From passive periphery to active agents: emerging perspectives in the archaeology of interregional interaction." American Anthropologist 104(3): 903-916. doi: 10.1525/aa.2002.104.3.903

Sundström, Susanne. 1995. Arkeologisk rapport över undersökning av bytomt, Rä̈ 56, Sävar sn, Västerbottens län, Västerbotten, samt rapport över miljöarkeologisk undersökning av Raä 56, udförd av Miljöarkeologiska laboratoriet vid Umeå universitetet. Excavation report, Umeå: Västerbottens Museum.

Symonds, James, Ylimaunu, Timo, Salmi, Anna-Kaisa, Nurmi, Risto. Kallio-Seppä, Titta, Kuokkanen, Tiina, Kuorilehto, Markku and Tranberg, Annemari. 2015. "Time, seasonality and trade: Swedish/Finnish - Sámi interactions in early modern Lapland." Historical Archaeology 49(3): 74-89. doi: 10.1007/BF03376973 
The version of record of this manuscript has been published and is available in American Anthropologist 120 vol. 4, 765-780. doi: 10.1111/aman.13104

Taavitsainen, Jussi-Pekka. 1990. Ancient Hillforts of Finland. Problems of Analysis, Chronology and Interpretation with Special Reference to the Hillfort of Kuhmoinen. Helsinki: Finnish Antiquarian Society.

Träsk, Olof. 1928. Kartor över Kemi \& Torne lappmarker 1642 och 1643. Stockholm: S.N.

Tanska, Terhi. 2011. "Asutusta ja kaupankäyntiä Iijoella." In Iin Vanhan Haminan kirkko ja hautausmaa. Arkeologisia tutkimuksia, edited by T. Kallio-Seppä, J. Ikäheimo and K. Paavola, 25-31. Oulu: University of Oulu.

Taskinen, Helena. 1998. ”Suomussalmen Tyynelänrannan hautalöytö.” In Rajamailla IV 1997, edited by K. Julku, 147-158. Rovaniemi: Pohjois-Suomen historiallinen yhdistys.

Vahtola, Jouko. 1980. Tornionjoki- ja Kemijokilaakson asutuksen synty. Nimistötieteellinen ja historiallinen tutkimus. Rovaniemi: Pohjois-Suomen historiallinen yhdistys.

Vahtola, Jouko. 1991. "Birkarlit 'pirkkalaiset'." In Tornionlaakson historia I, jääkaudelta 1600luvulle, edited by O. Rydberg, Y. Alamäki and M. Kenttä, 18-224. Haaparanta: Tornionlaakson kuntien historiakirjatoimikunta.

Vahtola, Jouko. 1998. "Katolisen kirkon ja uskonpuhdistuksen aika (noin 1350-1595)." In Iin seurakunnan historia, edited by K. Elo, R. Satokangas and J. Vahtola, 13-49. Ii: Iin seurakunta. 
The version of record of this manuscript has been published and is available in American Anthropologist 120 vol. 4, 765-780. doi: 10.1111/aman.13104

Vahtola, Jouko. 2004. Suomen historia. Jääkaudesta Euroopan unioniin. Helsinki: Otava.

Virrankoski, Pentti. 1973. Pohjois-Pohjanmaan ja Lapin historia III, Pohjois-Pohjanmaa ja Lappi 1600-luvulla. Oulu: Pohjois-Pohjanmaan, Kainuun ja Lapin Maakuntaliittojen yhteinen historiatoimikunta.

Virrankoski, Pentti. 1985. "1600-luku." In Faravidin maa. Pohjois-Suomen historia, edited by K. Julku, 200-234. Rovaniemi: Pohjois-Suomen historiallinen yhdistys.

Wallerstein, Immanuel. 1993. "World system vs. world-systems analysis." In The World System: Five Hundred Years or Five Thousand?, edited by A.G. Frank and B.K. Gills, 291-296. London: Routledge.

Wallerstein, Immanuel. 2004. World-systems Analysis, an Introduction. Durham and London: Duke University Press.

Wallerstein, Immanuel. 2011. The Modern World-System I. Capitalist Agriculture and the Origins of the European Word-Economy in the Sixteenth Century. With a New Prologue. Berkeley: University of California Press.

Wallerström, Thomas. 1995a. Norrbotten, Sverige och medeltiden: problem kring makt och bosättning i en europeisk periferi - del 1. Stockholm: Almqvist \& Wiksell international. 
The version of record of this manuscript has been published and is available in American Anthropologist 120 vol. 4, 765-780. doi: 10.1111/aman.13104

Wallerström, Thomas. 1995b. "De arkeologiska undersökningarna I G:a Kyrkbyn, Piteå landsförsamling." In Norrbotten Sverige och medeltiden. Problem kring makt och bosättning $i$ en europeisk periferi, Del 2, edited by T. Wallerström, 47-80. Stockholm: Almqvist \& Wiksell International.

Wallerström, Thomas. 1997. "On ethnicity as a methodological problem in historical archaeology: a northern Fennoscandian perspective." In Visions of the Past: Trends and Traditions in Swedish Medieval Archaeology, edited by H. Andersson, P. Carelli and L. Ersgård, 299-352. Stockholm: Central Board of National Antiquities.

Webster, Janet. 1997. "Necessary comparisons: a post-colonial approach to religious syncretism in the Roman provinces." World Archaeology 28(3): 324-338. doi: $10.1080 / 00438243.1997 .9980351$

Webster, Janet. 1999. "Resisting traditions: ceramics, identity, and consumer choice in the Outer Hebrides from 1800 to the present." Journal of Historical Archaeology 3(1): 53-73. doi: 10.1023/A:1022079315697

Webster, Janet. 2005. “Archaeologies of slavery and servitude: bringing 'New World' perspectives to Roman Britain." Journal of Roman Archaeology 18: 161-179. doi: $10.1017 / \mathrm{S} 10477759400007261$ 
The version of record of this manuscript has been published and is available in American Anthropologist 120 vol. 4, 765-780. doi: 10.1111/aman.13104

Wessman, Anna and Raninen, Sami. 2015. "Ristiretkiaika (1925/1100-1150/1300)." In Muinaisuutemme jäljet. Suomen esi- ja varhaishistoria kivikaudelta keskiajalle, edited by G. Haggrén, P. Halinen, M. Lavento, S. Raninen and A. Wessman, 337-363. Gaudeamus: Helsinki.

Zachrisson, Inger. 1984. De Samiska metalldepåerna år 1000-1350. Umeå: Umeå University. 


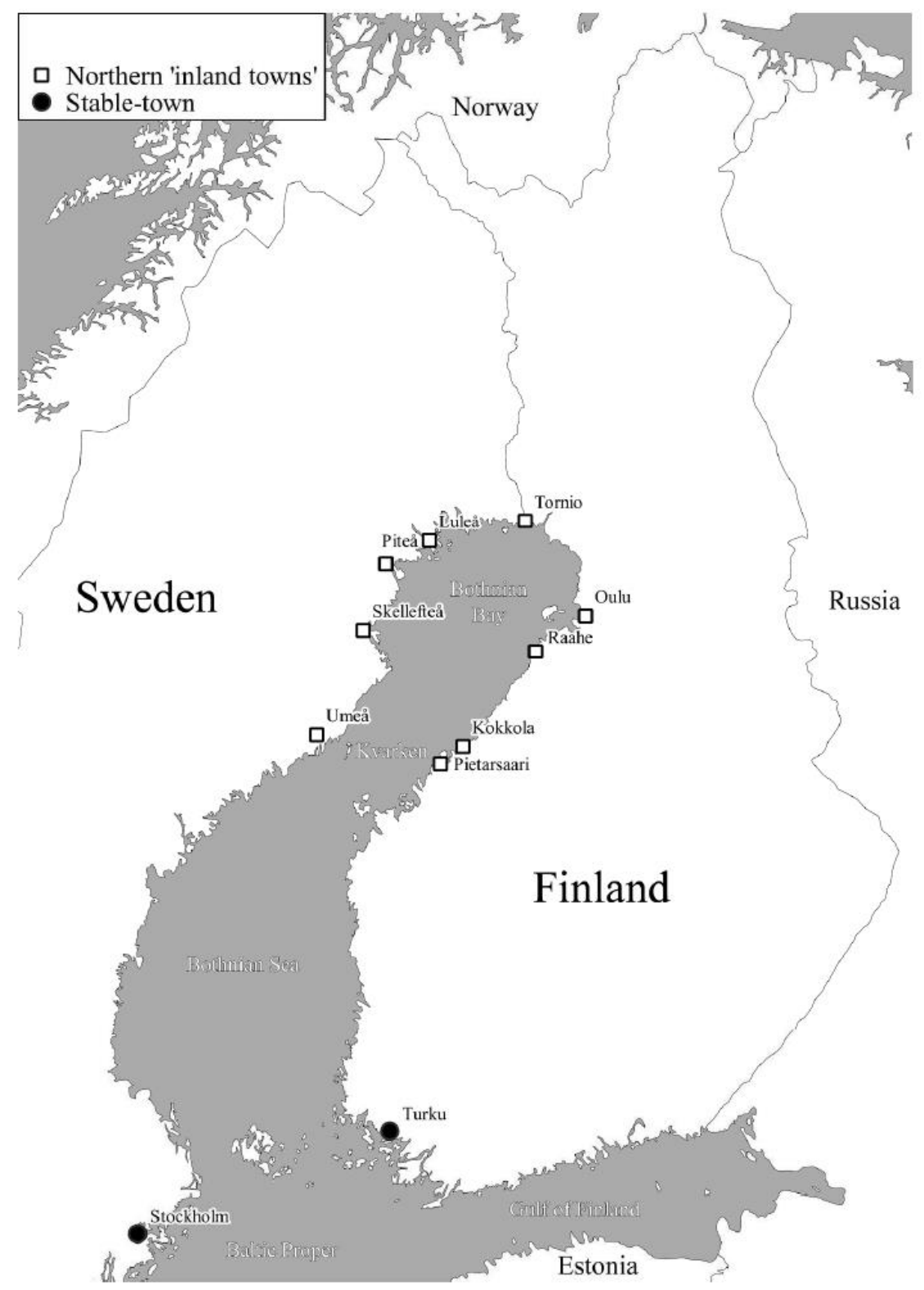

Figure 1 - Distribution of northern inland towns in the north in relation to the stable towns $210 \times 297 \mathrm{~mm}(300 \times 300 \mathrm{DPI})$ 


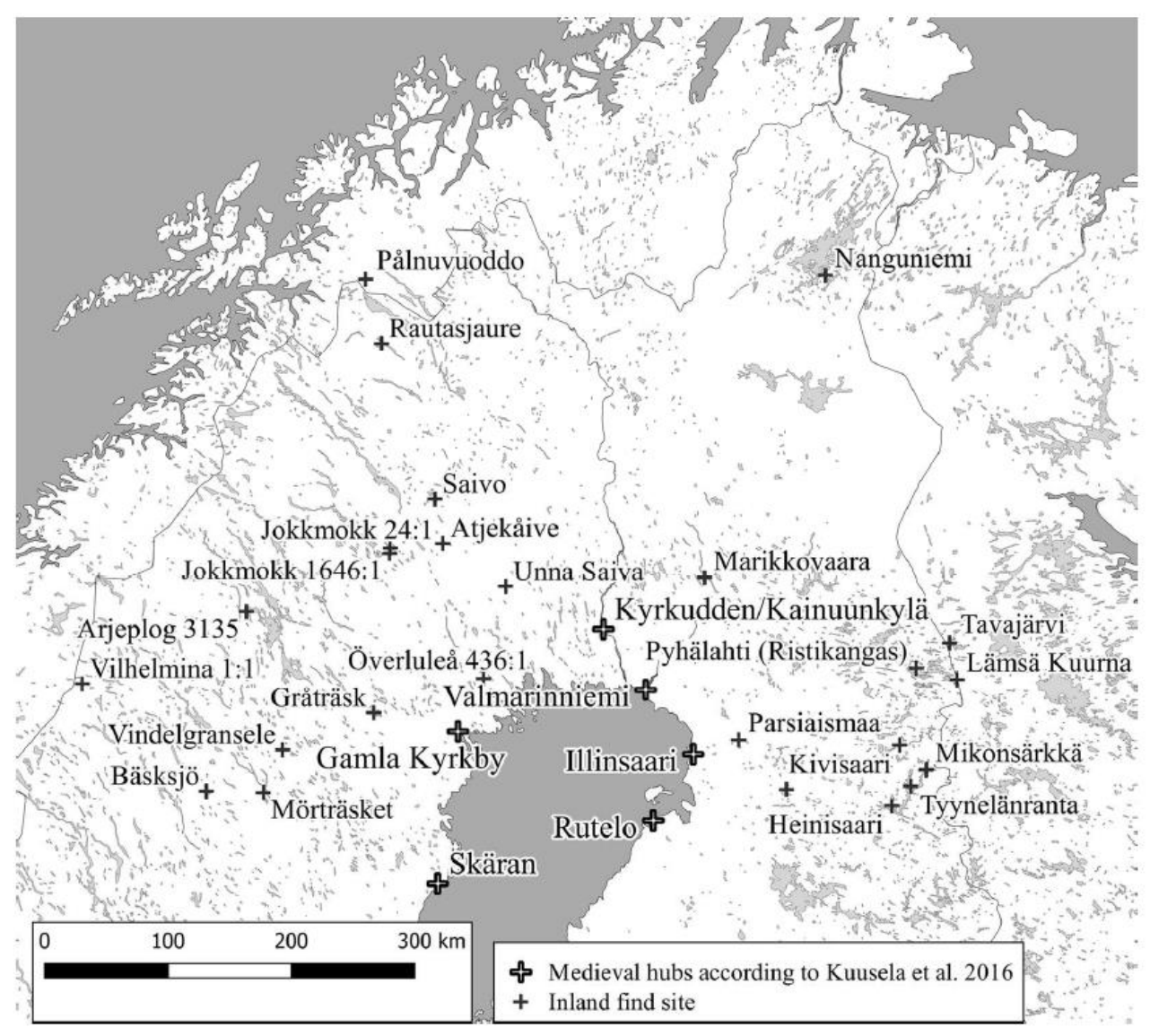

Figure 2 - Distribution of analysed archaeological sites

$149 \times 134 \mathrm{~mm}(300 \times 300 \mathrm{DPI})$ 


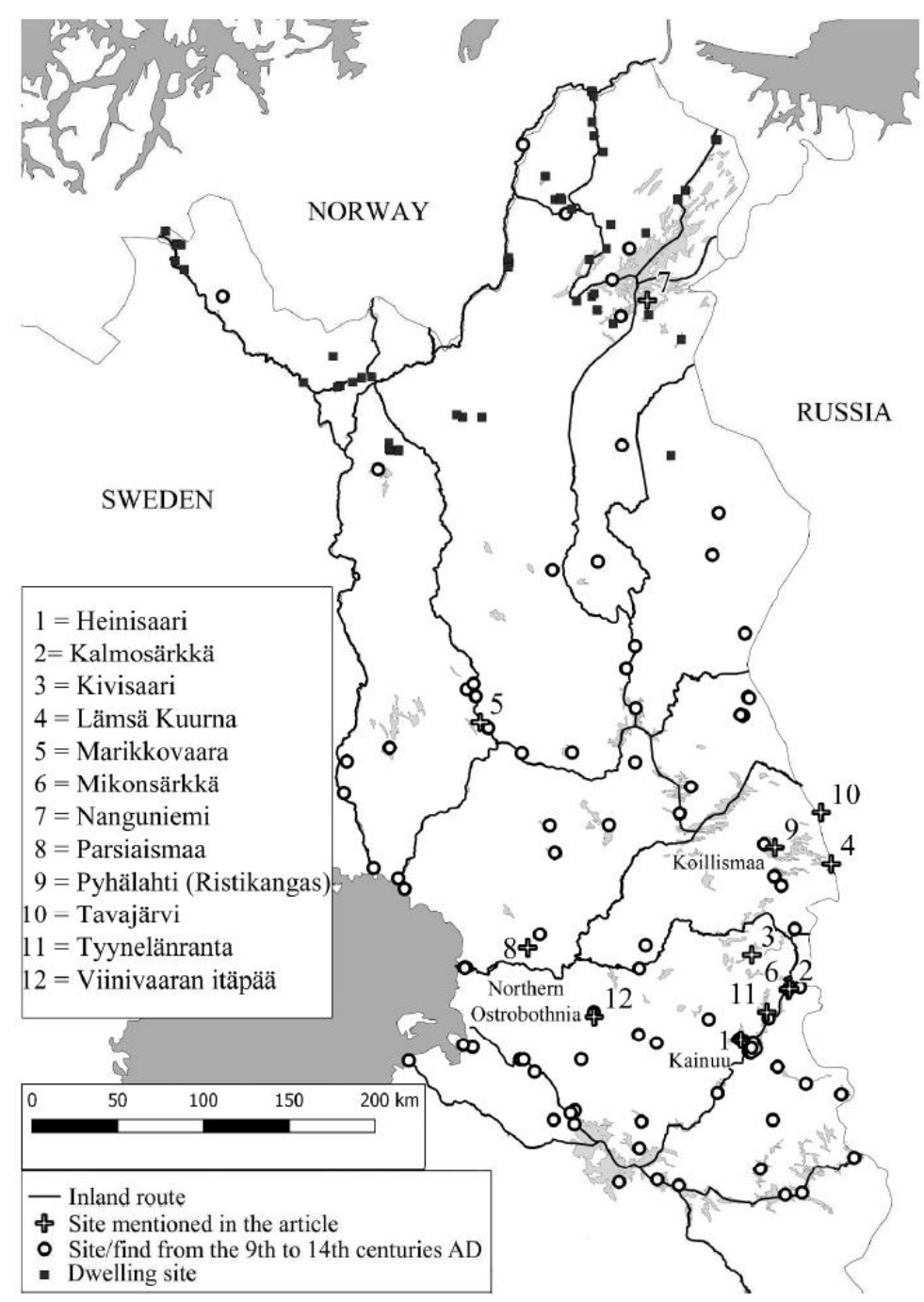

Figure 3 - Distribution of 9th-14th century sites in northern Finland in relation to historical inland travelling routes 
The version of record of this manuscript has been published and is available in American Anthropologist 120 vol. 4, 765-780. doi: 10.1111/aman.13104

\begin{tabular}{|c|c|c|c|c|}
\hline Located in & Site & Site type & Dating & Contacts to \\
\hline Finland & Heinisaari & $\begin{array}{l}\text { Cremation } \\
\text { burial }\end{array}$ & 11th century & Southwestern Finland, Central Europe, Scandinavia, Near- East \\
\hline Finland & Kalmosärkkä & $\begin{array}{l}\text { Multiperiod } \\
\text { dwelling site }\end{array}$ & $\begin{array}{l}\text { 12th-14th } \\
\text { century }\end{array}$ & Southwestern Finland, Russia \\
\hline Finland & Kivisaari & $\begin{array}{l}\text { Cremation } \\
\text { burial }\end{array}$ & 12th century & Southwestern Finland, East Baltic, Karelia \\
\hline Finland & Lämsä Kuurna & Silver deposit & $\begin{array}{l}\text { 12th-14th } \\
\text { century }\end{array}$ & Southwestern Finland, East Baltic, Scandinavia \\
\hline Finland & Marikkovaara & $\begin{array}{l}\text { Weapon } \\
\text { deposit }\end{array}$ & $\begin{array}{l}13 \text { th-14th } \\
\text { century }\end{array}$ & Central Europe, East Baltic, Karelia \\
\hline Finland & Mikonsärkkä & $\begin{array}{l}\text { Cremation } \\
\text { burial w. } \\
\text { multiperiod } \\
\text { dwelling site }\end{array}$ & 9th-11 th century & Southwestern Finland \\
\hline Finland & Nanguniemi & Silver deposit & $\begin{array}{l}12 \text { th-14th } \\
\text { century }\end{array}$ & Karelia, East Baltic \\
\hline Finland & Parsiaismaa & $\begin{array}{l}\text { Weapon } \\
\text { deposit }\end{array}$ & 12 th century & Karelia, Russia \\
\hline Finland & Pyhälahti (Ristikangas) & Coin deposit & 11th century & England, Germany, Denmark, Near-East \\
\hline $\begin{array}{l}\text { Russia } \\
\text { (surrendered } \\
\text { territory) }\end{array}$ & Tavajärvi & Silver deposit & $\begin{array}{l}11 \text { th- } 13 \text { th } \\
\text { century }\end{array}$ & Southwestern Finland, Karelia, East Baltic \\
\hline Finland & Tyynelänranta & $\begin{array}{l}\text { Disturbed } \\
\text { burial, likely a } \\
\text { cremation }\end{array}$ & $\begin{array}{l}13 \text { th-14th } \\
\text { century }\end{array}$ & Karelia, Russia \\
\hline Finland & Viinivaara $\mathrm{E}$ & $\begin{array}{l}\text { Cremation } \\
\text { burial \& } \\
\text { Multiperiod } \\
\text { dwelling site }\end{array}$ & 9th century & Southwestern Finland, East Baltic \\
\hline Sweden & Arjeplog 3135 & $\begin{array}{l}\text { Inhumation } \\
\text { burial }\end{array}$ & 10th century & Scandinavia, Near-East \\
\hline Sweden & Atjekăive & Metal deposit & 9th-14th century & Scandinavia/Central Europe \\
\hline Sweden & Bäsksjö & Metal deposit & 9th-14th century & Scandinavia/Central Europe \\
\hline Sweden & Gråträsk & Metal deposit & 8th-12th century & $\begin{array}{l}\text { Southwestern Finland, Karelia, Russia, Scandinavia/Central } \\
\text { Europe }\end{array}$ \\
\hline Sweden & Jokkmokk 1646:1 & Artefact deposit & 12th century & Southwestern Finland \\
\hline
\end{tabular}

\begin{tabular}{|l|l|l|l|l|l|}
\hline Sweden & & Jokkmokk 24:1 & $\begin{array}{l}\text { Inhumation } \\
\text { burial }\end{array}$ & 12 th century & Scandinavia, East Baltic, Southwestern Finland \\
\hline Sweden & & Mörtträsket & Metal deposit & $\begin{array}{l}10 \text { th-14th } \\
\text { century }\end{array}$ & Karelia, Russia, East Baltic, Scandinavia/Central Europe, Germany \\
\hline Sweden & & Överluleå 436:1 & $\begin{array}{l}\text { Inhumation } \\
\text { burial }\end{array}$ & 11 th century & Scandinavia, East Baltic \\
\hline Norway & & Pålnuvuoddo & Metal deposit & 8th-12th century & Scandinavia/Central Europe \\
\hline Sweden & & Rautasjaure & Metal deposit & 9th-14th century & Karelia, Russia, Scandinavia/Central Europe \\
\hline Sweden & & Saivo & Metal deposit & 9th-14th century & Southwestern Finland, Karelia, Scandinavia/Central Europe \\
\hline Sweden & & Unna Saiva & Metal deposit & 9 th-14th century & $\begin{array}{l}\text { Southwestern Finland, Karelia, Russia, Scandinavia/Central } \\
\text { Europe }\end{array}$ \\
\hline Sweden & & Vindelgransele & Metal deposit & 9th-14th century & Karelia, Russia, Scandinavia/Central Europe \\
\hline
\end{tabular}

